\title{
Communication \\ Lowering the Toxicity of Cd to Theobroma cacao Using Soil Amendments Based on Commercial Charcoal and Lime
}

\author{
Carla Calixta Calva Jiménez, Liliana Valentina Pinedo Fernández and Cristiano E. Rodrigues Reis *D
}

check for

updates

Citation: Calva Jiménez, C.C.; Pinedo Fernández, L.V.; Rodrigues Reis, C.E. Lowering the Toxicity of $\mathrm{Cd}$ to Theobroma cacao Using Soil Amendments Based on Commercial Charcoal and Lime. Toxics 2022, 10, 15. https://doi.org/10.3390/ toxics10010015

Academic Editors: Ilektra Sperdouli and Miguel Pedro Mourato

Received: 14 November 2021 Accepted: 29 December 2021 Published: 4 January 2022

Publisher's Note: MDPI stays neutral with regard to jurisdictional claims in published maps and institutional affiliations.

Copyright: (C) 2022 by the authors. Licensee MDPI, Basel, Switzerland. This article is an open access article distributed under the terms and conditions of the Creative Commons Attribution (CC BY) license (https:// creativecommons.org/licenses/by/ $4.0 /)$.
EARTH University, Las Mercedes, Guacimo 4442-1000, Limon, Costa Rica; ccalva@earth.ac.cr (C.C.C.J.); lpinedo@earth.ac.cr (L.V.P.F.)

* Correspondence: crodrigues@earth.ac.cr; Tel.: +506-2713-0000 (ext. 3313)

\begin{abstract}
Carbonaceous and calcareous materials are commonly used as amendments to decrease the $\mathrm{Cd}$ mobility in contaminated soils. This study evaluated the effect of amendments applied to cocoa seedlings in the greenhouse, considering the mobilization of soil cadmium toward the seedlings as the main response. The experimental conditions considered soil artificially contaminated with $\mathrm{Cd}$ at a concentration of $50 \mathrm{mg} \mathrm{Cd} \mathrm{kg}^{-1}$ and applications of amendments in different treatments with the presence of charcoal dust and calcium carbonate. The charcoal was characterized by microscopy and by adsorption tests, and it proved to be a material with macropores, with a maximum capacity of $8.06 \mathrm{mg} \mathrm{Cd} \mathrm{g}^{-1}$ and favorable kinetic behavior according to the adjustment of the data obtained to the pseudo-second-order model. The results also showed that the application of liming decreased the mobility of $\mathrm{Cd}$ toward the seedlings, with the liming combined with charcoal leading to the absence of $\mathrm{Cd}$ in the cocoa seedlings, considering a residual concentration of $\mathrm{Cd}$ in the soil of $35 \mathrm{mg} \mathrm{Cd} \mathrm{kg}^{-1}$. The results, although limited to a small scale, demonstrated the possibility of applying low-cost and easy-to-handle amendments for the control of $\mathrm{Cd}$ in cocoa plantations.
\end{abstract}

Keywords: adsorption; cadmium; charcoal; liming; heavy metal

\section{Introduction}

Cacao (Theobroma cacao) is an important crop for many developing countries within the tropical zone, with countries in the tropics and subtropics of Africa, Latin America, and Southeast Asia as the largest producers in the world [1,2]. Cacao plantations have been considered as an attractive crop due to the relatively low initial capital investment combined with well-established conventional crop protection approaches [2].

Over the past decades, some reports indicated that cacao plants reaching processing centers were contaminated with worrisome levels of heavy metals, including mercury, lead, arsenic, and cadmium [3]. Among these metals, cadmium toxicity has gained particular interest due to the health effects of kidney malfunction and bone deterioration associated with the consumption of contaminated feed and food materials [4]. Cadmium has rapid mobility in cacao plants, and it can be easily absorbed by the roots and accumulate in the seeds, leading to cacao-derived products with toxic concentrations of this heavy metal $[5,6]$. Cadmium toxicity causes growth-related and metabolic defects, such as browning of plant roots and chlorosis. Such defects lead to modifications in P and N uptake and transport, yielding Fe uptake and decreased nitrogen fixation, affecting the photosynthetic efficiency of the plants [6]. The sources of cadmium in tropical soils are reviewed elsewhere and can be summarized by anthropogenic practices, such as the dumping of mining residues, industrial effluents, coal, and other materials, which, over the years, lead to detectable concentrations in acid soils [4].

Cadmium remediation in tropical soils can be achieved through, among other technologies, the application of liming and adsorbing materials [7,8]. According to Hamid et al. [7], an effective cadmium management practice involves the change of its form, which 
is dependent on $\mathrm{pH}$, and its immobilization on solid matrices. Such solid materials are usually porous and may facilitate the binding of cadmium ions onto their surface. Some of these materials include activated carbon, biochar, organic wastes, zeolites, and others [7]. These in situ amendments have been described as a viable solution to some of the problems associated with $\mathrm{Cd}$ contamination in productive soils. The mechanisms involved in these soil amending processes are based on precipitation, adsorption, ion exchange, and complexation, leading to decreased mobility and bioavailability in soils [9].

Considering that the remediation of Cd-contaminated soils is often laborious and cost-inhibitive, the objective of this work was to evaluate the use of commercial charcoal and lime in lowering the concentration of $\mathrm{Cd}$ in cacao grown in tropical soil. Given the relative scarcity of the adsorbing characteristics of vegetable charcoal, which is not as often evaluated as an adsorber for heavy metals in soils, this study also carried out some preliminary characterization in terms of controlled adsorption of $\mathrm{Cd}$ ions in aqueous solutions. In this sense, a set of experiments were carried out using Cd-contaminated soils amended with treatments based on charcoal, lime, and the combination of both to evaluate Cd mobility toward different parts of the cacao plant.

\section{Materials and Methods}

\subsection{Characterization of the Vegetable Charcoal: Microscopic and Adsorption Potential Analyses}

Vegetable charcoal was obtained from a local supermarket in the district of Limón in Costa Rica. The charcoal was ground using a manual grinder and sieved through a 10-mesh screen to provide $2 \mathrm{~mm}$ or lower charcoal powder and granules. The charcoal was then characterized at the Research Center in Microscopic Structures (CIEMIC) at the University of Costa Rica (San José, Costa Rica) using a Hitachi S-570 Scanning Electron Microscope set to a voltage of $15 \mathrm{kV}$.

The adsorption potential of the carbon was evaluated using batch adsorption assays with charcoal powder samples and a $\mathrm{Cd}\left(\mathrm{NO}_{3}\right)_{2} \cdot 4 \mathrm{H}_{2} \mathrm{O}$ (Sigma-Aldrich, Saint Louis, MO, USA) stock solution at a concentration of $200 \mathrm{mg} \mathrm{Cd} \mathrm{L}^{-1}$ from which the samples for the respective dilutions of each cluster of experiments were taken from. The adsorption assays were carried out to evaluate its kinetic behavior, the effect of the medium $\mathrm{pH}$ on the adsorption process, and the isotherm profile of the adsorption of $\mathrm{Cd}$ ions onto the charcoal powder. All the adsorption assays were carried out at $50 \mathrm{~mL}$ conical tubes with $40.0 \mathrm{~mL}$ of the $\mathrm{Cd}\left(\mathrm{NO}_{3}\right)_{2} \cdot 4 \mathrm{H}_{2} \mathrm{O}$ solution and $0.050 \mathrm{~g}$ of charcoal. The tubes were placed onto an orbital shaker set at $180 \mathrm{rpm}$ at $25^{\circ} \mathrm{C}$. The supernatant was then recovered using a Whatman \#2 paper filter, and the concentration of $\mathrm{Cd}$ ions was determined on the liquid phase via complexometric EDTA titration.

The $\mathrm{pH}$ assays were conducted using the $\mathrm{Cd}\left(\mathrm{NO}_{3}\right)_{2} \cdot 4 \mathrm{H}_{2} \mathrm{O}$ solution at $20 \mathrm{mg} \mathrm{Cd} \mathrm{L}-1$ under the $\mathrm{pH}$ values of 3.5, 5.0, 6.5, and 8.0, which were adjusted using $\mathrm{HCl}$ or $\mathrm{NaOH}$ solutions at $1.0 \mathrm{~mol} \mathrm{~L}^{-1}$ for $6 \mathrm{~h}$. The kinetic assays were also carried out using a $\mathrm{Cd}\left(\mathrm{NO}_{3}\right)_{2} \cdot 4 \mathrm{H}_{2} \mathrm{O}$ solution at $20 \mathrm{mg} \mathrm{Cd} \mathrm{L}^{-1}$, with sampling times ranging from $0.1 \mathrm{~h}$ up to $24 \mathrm{~h}$. The data for the adsorption isotherm analysis were acquired from a set of experiments varying the concentration of the $\mathrm{Cd}\left(\mathrm{NO}_{3}\right)_{2} \cdot 4 \mathrm{H}_{2} \mathrm{O}$ solution from 2 up to $200 \mathrm{mg} \mathrm{Cd} \mathrm{L}^{-1}$ within $6 \mathrm{~h}$ of the assay. In all cases, the amount of $\mathrm{Cd}$ adsorbed onto the charcoal powder was estimated via a mass balance approach, considering the difference in concentration of $\mathrm{Cd}$ ions at the solution used for a given assay and the concentration of $\mathrm{Cd}$ ions at the supernatant of such assay, as described in Equation (1):

$$
q=\frac{\left(C_{0}-C_{f}\right) V}{m}
$$

Equation (1) relates the concentration of $\mathrm{Cd}$ adsorbed onto the charcoal powder $q$ in

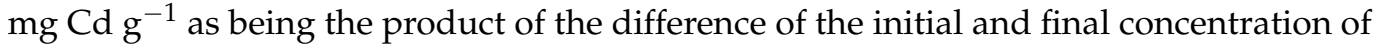
$\mathrm{Cd}$ in $\mathrm{mg} \mathrm{Cd} \mathrm{L}{ }^{-1}$ as $C_{0}$ and $C_{f}$, respectively, with the volume $V$ of the solution used in the assay in $\mathrm{L}$ divided by the mass of the charcoal powder $m$ used for such assay in $\mathrm{g}$. 


\subsection{Field Evaluation of the Amendments}

The field experiments took place at an open greenhouse in Limón province in Costa Rica $\left(10^{\circ} 12^{\prime} 38^{\prime \prime} \mathrm{N}\right.$ and $83^{\circ} 35^{\prime} 47^{\prime \prime} \mathrm{W}, 40 \mathrm{~m}$ above sea level). The average temperature of the test site is $25.1^{\circ} \mathrm{C}$, with an average relative humidity of $83.5 \%$ and annual precipitation of $3592.2 \mathrm{~mm}$. The soil used in the experiments was characterized as an inceptisol, according to the USDA classification and possessed no detectable total $\mathrm{Cd}$. The soil $\mathrm{pH}$ in water was recorded as 5.28 .

Three different treatments and a control were evaluated in triplicate in this study. Each experimental condition consisted of a plant pot filled with soil dosed with a solution of $\mathrm{Cd}\left(\mathrm{NO}_{3}\right)_{2} \cdot 4 \mathrm{H}_{2} \mathrm{O}$ to provide an initial $\mathrm{Cd}$ concentration of $50 \mathrm{mg} \mathrm{Cd} \mathrm{kg}^{-1}$ soil with cacao seedlings of approximately $40 \mathrm{~cm}$ in height. Each plant pot carried approximately $6.75 \mathrm{~kg}$ of soil with a moisture content of approximately $19.85 \%$. A total of 12 round plant pots (22 cm height $\times 22.5 \mathrm{~cm}$ diameter, with a superficial area of $397 \mathrm{~cm}^{2}$ ), each corresponding to a repetition of treatment, were placed in the greenhouse, each one being $30 \mathrm{~cm}$ apart from each other. The plant pots were assigned random spots on the greenhouse to lower variability bias.

The treatments were based on the presence of charcoal amended to the soil, on the application of superficial lime (agricultural grade $\mathrm{CaCO}_{3}$ ), or both. The estimation of the amount of charcoal is derived from the study of Bian et al. [10], who reported a ratio of $40 \mathrm{t}$ of biochar per ha of Cd-contaminated soil in a field evaluation in China. Following the ratio described by Bian et al. [10], the proportional amount of charcoal powder added to the treatments that required charcoal was $160 \mathrm{~g}$ of charcoal powder per plant pot. Charcoal powder was mixed with the soil using perforated cellulose teabags, each one containing approximately $40 \mathrm{~g}$ of charcoal powder, which were easy to harvest at the end of the experiment. On the other hand, the estimation for the liming requirement of this soil was based on the development of a liming curve of the soil with $\mathrm{CaCO}_{3}$. The estimation of the liming requirement of this soil was $4.2 \mathrm{t}$ of $\mathrm{CaCO}_{3}$ per ha of soil, corresponding to $16.7 \mathrm{~g}$ of $\mathrm{CaCO}_{3}$ per soil plant. $\mathrm{CaCO}_{3}$ was applied on the first day of the experiment through a powder dispersion onto the surface of the soil on the plant pot. Each plant pot was irrigated with $150 \mathrm{~mL}$ of distilled water every 2 days. The experimental conditions were evaluated for a total of 60 days. $\mathrm{pH}$ analysis of the soil was assessed in water [11]. At the end of the experiment, each seedling was cut into the corresponding fractions of roots, stem, and leaves, all of which were thoroughly washed. The soil and the charcoal bags were collected and stored before the subsequent analyses.

$\mathrm{Cd}$ ions in soil and charcoal powders were assayed as total $\mathrm{Cd}$ based on $\mathrm{HNO}_{3}$ digestion of such samples using a microwave-adapted method from Carter and Gregorich [11]. $\mathrm{Cd}$ in plant samples was assessed following drying at $60{ }^{\circ} \mathrm{C}$, following microwave digestion, also adapted from Carter and Gregorich [11]. The microwave system used for sample preparation was a Perkin Elmer Titan MPS, with a maximum power of $1500 \mathrm{~W}$. The quantification of $\mathrm{Cd}$ in the samples was processed using a Perkin Elmer 8300 Induction Coupled Plasma with Optical Emission Spectroscopy (ICP-OES) system. Statistical analysis was carried out using OriginPro ${ }^{\circledR} 16$.

\section{Results}

\subsection{Charcoal Characterization and Cd Adsorption Potential}

The characterization of the charcoal powder used in the experiments via Scanning Electron Microscopy (SEM) demonstrated the material to be an amorphous and porous material. Figure 1 highlights the micrographs of the charcoal powder under different scales and the dimensioning of typical powder sizes and the diameter of the pores. 


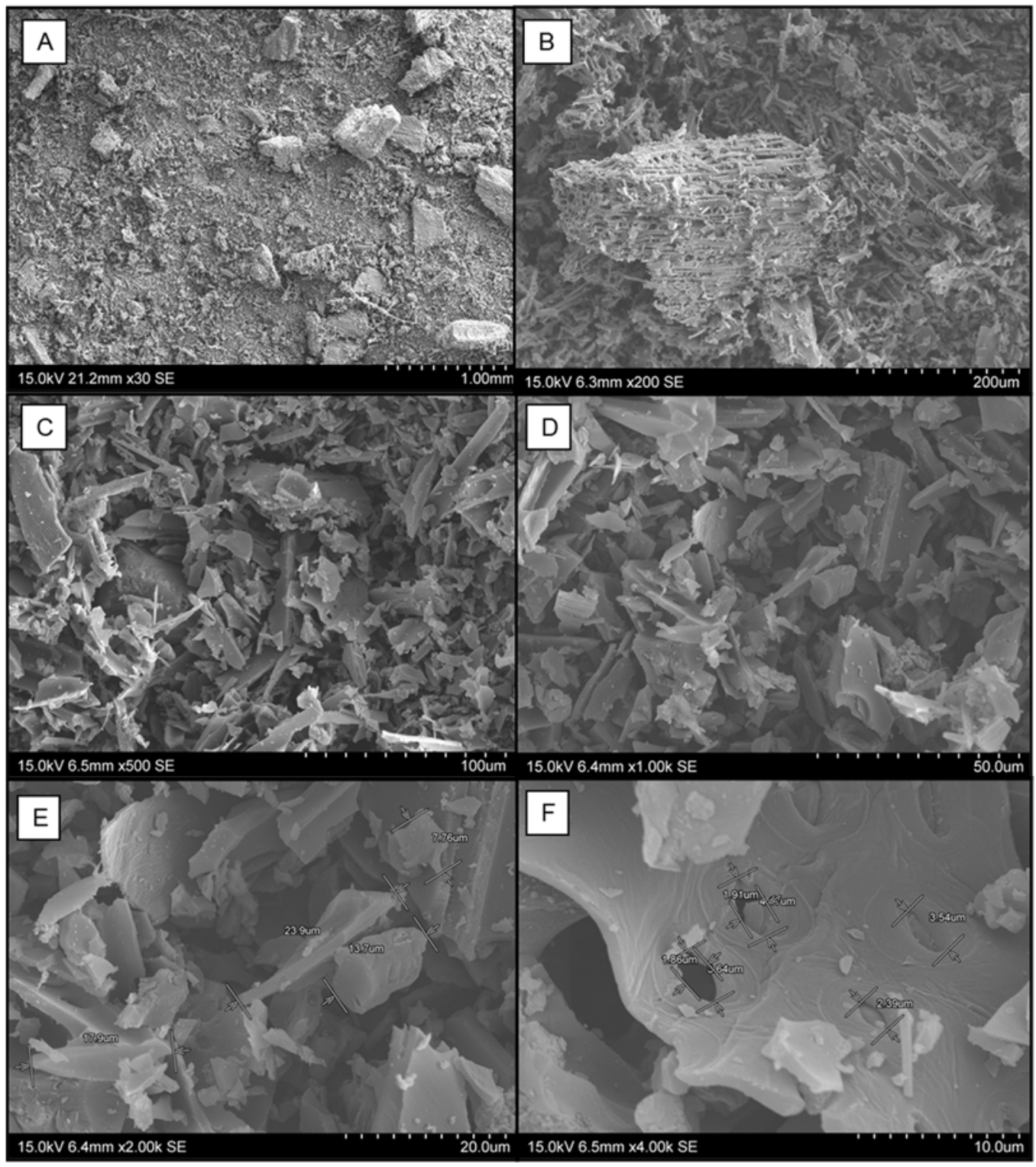

Figure 1. SEM micrograph of the charcoal powder used in the experiments with readings at a $15 \mathrm{kV}$ acceleration voltage under high vacuum and different scales: $(A) \times 30,($ B $) \times 200,($ C $) \times 500,($ D) $\times 1000$, (E) $\times 2000$, and $(\mathbf{F}) \times 4000$.

As it can be seen from Figure 1C-E, the charcoal powder presented a highly amorphous structure. It can also be seen the disorganized and unstructured morphology, which is typical of carbonaceous materials [12]. Even though the charcoal powder was ground to a $2 \mathrm{~mm}$ threshold, from a qualitatively perspective, it can also be seen the wide distribution of the granule size of the powder material. Figure 1E illustrates the sizing of small granules to be as small as $7.76 \mu \mathrm{m}$, with other particulates in the micron range, which could lead to a suspension-like fluid behavior in the soil solution. Finally, the diameter of the pores in the larger range granules, observed in Figure $1 \mathrm{~F}$, is within a range of $1.8 \mu \mathrm{m}$ to $4.0 \mu \mathrm{m}$. According to the IUPAC classification [13], such pores can be classified as both open and closed pores, within the macro range, since all the recordings are greater than the $50 \mathrm{~nm}$ threshold of the definition of macropores. These structures, according to Kurniawan and Ismadji [14], have been demonstrated to be feasible in aiding the adsorption of ions with a kinetic behavior majorly controlled by diffusion mechanisms.

The adsorption behavior of $\mathrm{Cd}$ ions was analyzed in terms of the kinetics, the isotherm building, and the medium $\mathrm{pH}$. The kinetic behavior of the adsorption of $\mathrm{Cd}$ ions onto the 
charcoal powder in a controlled environment was demonstrated to be quick and highly efficient under the conditions applied to the study. Figure 2 illustrates the kinetic behavior of the adsorption.

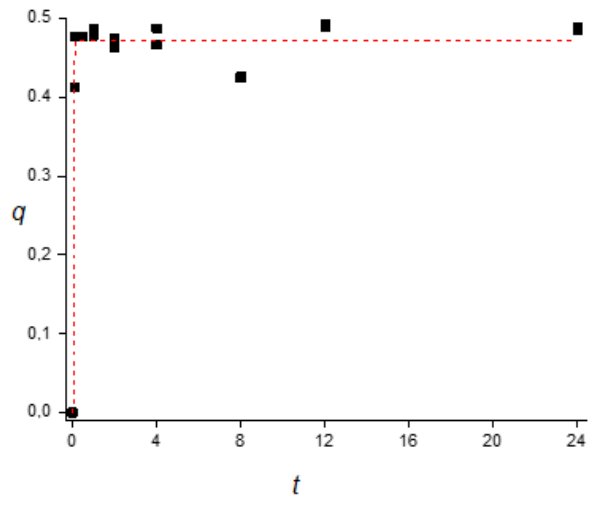

(A)

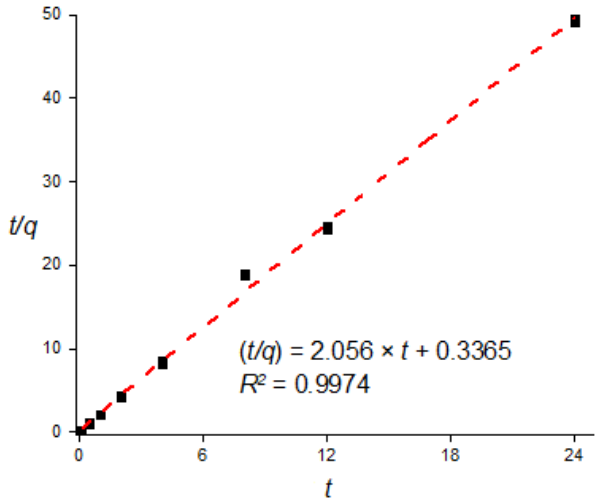

(B)

Figure 2. (A) Plot of $\mathrm{Cd}$ ions adsorbed onto the charcoal powder, measured as $\mathrm{q}(\mathrm{mg} / \mathrm{g})$ against time (h), illustrating the adsorption kinetic profile of $\mathrm{Cd}$ ions onto charcoal powder considering a volume of $\mathrm{Cd}\left(\mathrm{NO}_{3}\right)_{2} \cdot 4 \mathrm{H}_{2} \mathrm{O}$ solution of $40.0 \mathrm{~mL}$ at a concentration of $20 \mathrm{mg} \mathrm{Cd} \mathrm{L}^{-1}$ with $0.050 \mathrm{~g}$ of charcoal powder. (B) Plot of the ratio of the time and the concentration of $\mathrm{Cd}$ ions adsorbed onto the charcoal powder, calculated as $\mathrm{t} / \mathrm{q}$, in units of $\mathrm{h} \cdot \mathrm{g} / \mathrm{mg}$ against time, measured in $\mathrm{h}$, representing the kinetic data adjusted to the linearized function of pseudo-second-order behavior.

Apart from the fact that there is a plateau concentration range after the first data points, the kinetic plot as described in Figure 2A cannot describe the adsorption behavior of $\mathrm{Cd}$ onto charcoal powder from a wider perspective. Therefore, given the considerations from Azizian [15], who described that pseudo-second-order kinetic models often are approachable by adsorbing conditions with low concentrations of the adsorbate, the kinetic data were treated to plot the ratio of time over concentration of $\mathrm{Cd}$ on the charcoal powder $\left(t / q\right.$, with units of $\left.h \cdot g_{\text {charcoal }} \cdot \mathrm{mg}^{-1} \mathrm{Cd}\right)$ as a function of the time $(t$, with $\mathrm{h}$ as a unit). Equation (2) describes the linearized version of a pseudo-second-order model as described by Azizian [15], in which $k_{2}$ is a pseudo-second-order constant and $q_{e}$ is the saturation concentration of the adsorbate at equilibrium:

$$
\frac{t}{q}=\frac{1}{k_{2} q_{e}^{2}}+\frac{1}{q_{e}} t
$$

The kinetic data had a strong correlation with the adjustment proposed by the pseudosecond-order model, demonstrated by the value of the $R^{2}$ of the linearization greater than 0.997. The linearization also led to the estimation of the theoretical value of $q_{e}$ as being $0.48 \mathrm{mg} \mathrm{Cd} \mathrm{g}^{-1}$, which is close to the experimental data from Figure 2A. The value of $k_{2}$ was estimated to be $12.56 \mathrm{~g} \mathrm{mg}^{-1} \mathrm{~min}^{-1}$, which is close to other reports in the literature considering adsorptions systems alike.

The isotherm curve, prepared for an initial range of concentration of $\mathrm{Cd}$ ions within 2 to $200 \mathrm{mg} \mathrm{L}^{-1}$ demonstrates a typical isothermal behavior, in which an increase in the initial concentration of the adsorbate leads to higher saturation values onto the adsorbent. Given the relatively low range of concentration of the adsorbent, an initial analysis of the isotherm curve does not provide enough information for the prediction of the maximum equilibrium capacity of the adsorbent with $\mathrm{Cd}$ ions as adsorbates. Figure 3 highlights such observations. 


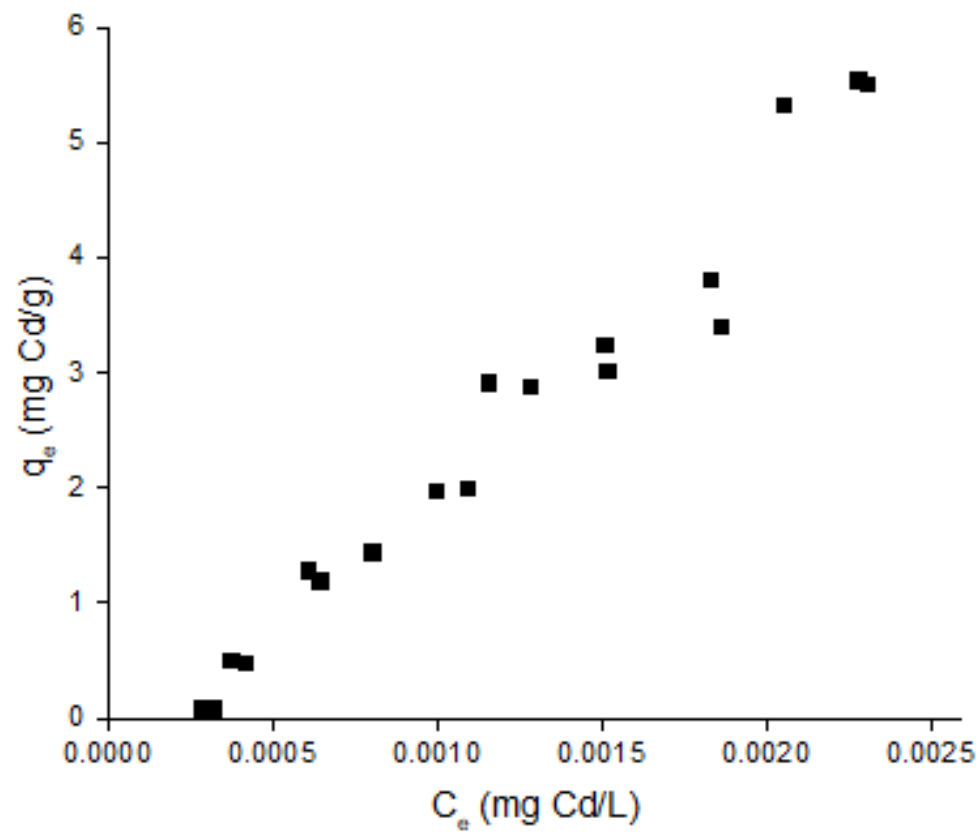

Figure 3. Plot of the concentration of $\mathrm{Cd}$ ions adsorbed onto the charcoal powder at equilibrium $\left(q_{e}\right)$, estimated using units of $\mathrm{mg} / \mathrm{g}$ against the concentration of $\mathrm{Cd}$ ions in solution at equilibrium $\left(C_{e}\right)$ with units of $\mathrm{mg} / \mathrm{L}$, representing the isotherm curve of $\mathrm{Cd}$ ions onto commercial charcoal powder, considering a range of initial concentrations of $\mathrm{Cd}$ from 2 to $200 \mathrm{mg} \mathrm{L}^{-1}$ with assay volumes of $40.0 \mathrm{~mL}$ at a concentration of with $0.050 \mathrm{~g}$ of charcoal powder for $6 \mathrm{~h}$ of contact time.

The data described in Figure 3, which details all the experimental points obtained for the isotherm interpretation, were adjusted to the Langmuir and the Freundlich adsorption models. The Langmuir model, which relates the concentration of the adsorbate $C_{e}$ at its equilibrium time [15], with the saturation of the adsorbent at equilibrium $q_{e}$, is presented as Equation (3). The constants $b$ and $q_{\max }$ on the Langmuir model are described as the Langmuir constant and the maximum saturation capacity of the adsorbent at its equilibrium, respectively. Equation (4) displays a linearized version of the Langmuir model. The Freundlich model, which is based on empirical observations between the adsorbent capacity and the concentration of the adsorbate taking into consideration the surface adsorption energy, relates $q_{e}$ with $C_{e}$ to the power of $\mathrm{n}^{-1}$ through the Freundlich constant A [15], as displayed as Equation (5). A common linearization of the Freundlich model is achieved through a logarithmic adjustment of the function, displayed as Equation (6).

$$
\begin{gathered}
q_{e}=\frac{q_{\max } b C_{e}}{1+b C_{e}} \\
\frac{1}{q_{e}}=\frac{1}{q_{\max } b C_{e}}+\frac{1}{q_{\max }} \\
q_{e}=A C_{e}^{\frac{1}{n}} \\
\log q_{e}=\log A+\frac{1}{n} \log C_{e}
\end{gathered}
$$

Figure 4 illustrates the correlation of the adsorption isotherm data to the linearized Langmuir and Freundlich models. If the whole data range was to be adjusted to the linearized Langmuir model, the y-axis intercept, corresponding to the value of $q_{\text {max }}$, would be negative, which is impossible from the standpoint of the interpretation of the physical behavior of the phenomena involved in the process. Azizian [15] describes that this fact can be attributed to the low concentration of the adsorbent within the range taken for the analysis. Therefore, if the numerical analysis takes into consideration the values 
considering the initial concentration of $\mathrm{Cd}$ equal to or greater than $175 \mathrm{mg} \mathrm{L}^{-1}$ within the whole range studied, the regression indicates a $q_{\max }$ value of $8.06 \mathrm{mg} \mathrm{Cd} \mathrm{g}^{-1}$ with $\mathrm{R}^{2}=0.8764$. Similar behavior is attributed to the linearized Freundlich isotherm, in a sense that the analysis of all the data points leads to a conclusion that the adsorption phenomenon is not thermodynamically favorable due to the parameter $\mathrm{n}^{-1}$ being greater than 1. Nonetheless, the analysis from the data considering the initial concentration of $\mathrm{Cd}$ equal to or greater than $175 \mathrm{mg} \mathrm{L}^{-1}$ leads to a value of $\mathrm{n}^{-1}$ of 0.3266 with $\mathrm{R}^{2}=0.8764$, which fits within the range of thermodynamically favorable adsorption kinetic processes. Figure 4 highlights the whole data range as the black squares and the data points taken for the estimation of the aforementioned parameters.

A)

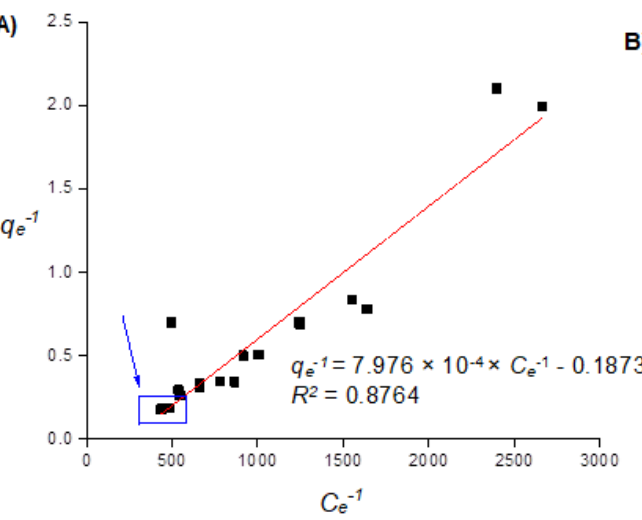

B) $\log q_{e}=1.644 \log C_{e}+5.115$

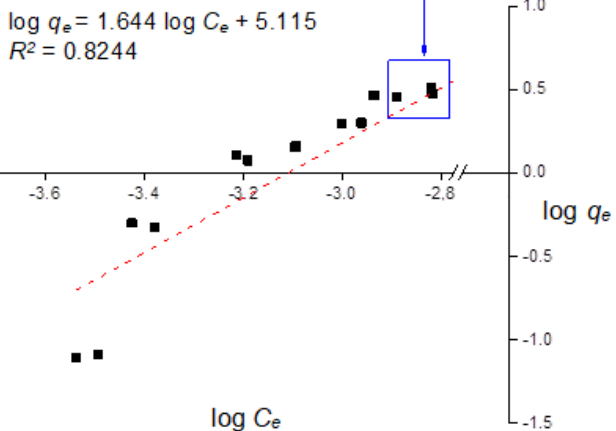

$\log C_{e}$

Figure 4. (A) Linearized Langmuir model, plotted with the inverse value of the Cd adsorbed capacity at equilibrium $\left(1 / q_{e}\right.$ in units of $\left.\mathrm{g} / \mathrm{mg}\right)$ against the inverse of the $\mathrm{Cd}$ ions in solution at equilibrium $\left(1 / C_{e}\right.$ in units of $\left.\mathrm{L} / \mathrm{mg}\right)$, and $(\mathbf{B})$ linearized Freundlich model, plotted as the logarithm of the adsorbate capacity in terms of $\mathrm{Cd}$ adsorbed onto the charcoal powder $\left(\log q_{e}\right)$ against the logarithm of the concentration of the $\mathrm{Cd}$ ions remaining in solution $\left(\log C_{e}\right)$, both at equilibrium, adjusted to the isotherm profile of a range of initial concentrations of $\mathrm{Cd}$ from 2 to $200 \mathrm{mg} \mathrm{L}^{-1}$ with assay volumes of $40.0 \mathrm{~mL}$ at a concentration of with $0.050 \mathrm{~g}$ of charcoal powder for $6 \mathrm{~h}$ of contact time.

The effects of the medium $\mathrm{pH}$ were evaluated, taking into consideration a range from 3.5 to 8.0. As it can be seen from Figure 5, the confidence intervals of $q_{e}$ obtained from data points at $\mathrm{pH} 3.5,5.0$, and 6.5 do not allow the interpretation that they are different from a statistical standpoint. While there were some experimental discrepancies considering the error of the measurements, expressed as the error bars in Figure 5, there is an indication that the results under $\mathrm{pH}$ of 5 and 6.5 tend to be higher than those under alkaline conditions. The value of $q_{e}$ measured for an alkaline $\mathrm{pH}$ leads to the observation that there should be some kinetic or mass transfer difficulties in the adsorption process. According to Oyetade et al. [16], Cd ions, which behave as $\mathrm{Cd}^{2+}$ in $\mathrm{pH}$ values lower than 7.0 , may be present as $\mathrm{Cd}(\mathrm{OH})^{+}$in basic solutions. The change in the form of $\mathrm{Cd}$ ions may be one of the reasons that explain the difference in the adsorption behavior in different behavior, which can be summed with the potential changes in the surface characteristics of the charcoal powder. 


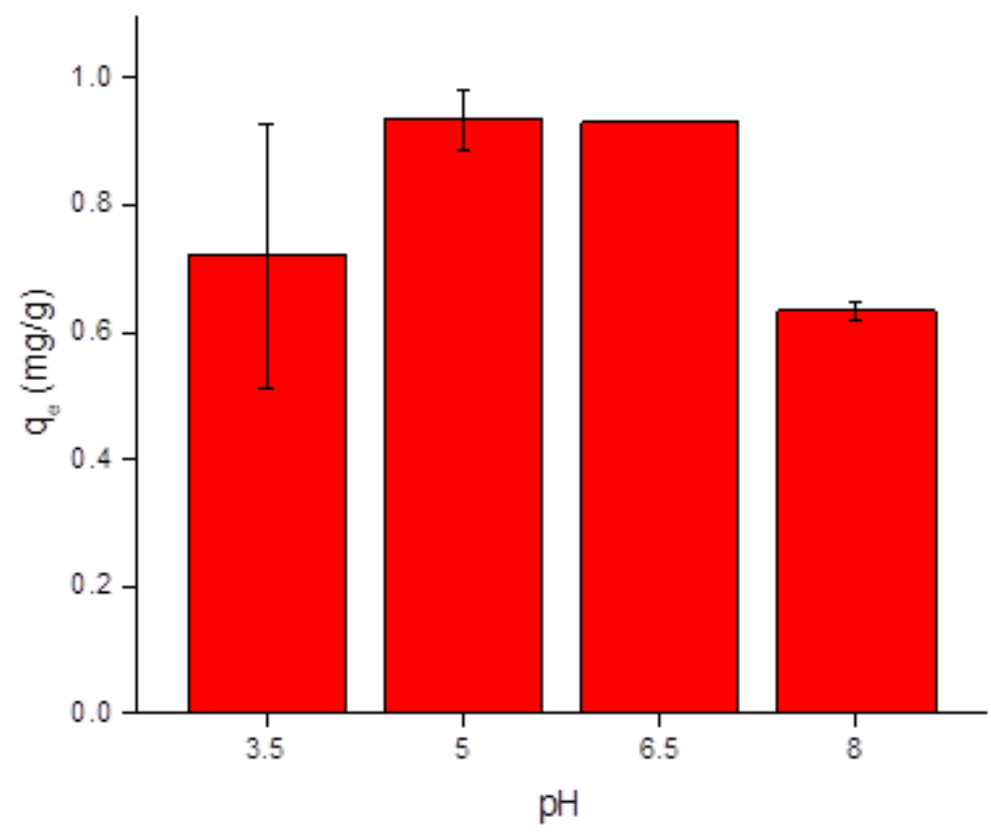

Figure 5. Plot of adsorbed cadmium at equilibrium $\left(q_{e}\right.$, measured in $\left.\mathrm{mg} / \mathrm{g}\right)$ against the initial $\mathrm{pH}$ of the aqueous solution containing $\mathrm{Cd}$ ions, demonstrating the effect of $\mathrm{pH}$ on the adsorption of $\mathrm{Cd}$ ions onto the commercial charcoal powder.

\subsection{Application of Charcoal and Lime Amendments: Effects on Cd Mobility}

The analysis of the average composition of the T. cacao seedlings used in this work indicated a concentration of $0.22 \mathrm{mg} \mathrm{Cd} \mathrm{kg}^{-1}$; meanwhile, the soil used for transplanting the seedlings contained no detectable total $\mathrm{Cd}$ at the beginning of the experiment. The soil, which was then dosed with $\mathrm{Cd}$ to a concentration of $50 \mathrm{mg} \mathrm{Cd} \mathrm{kg}^{-1}$ also did not yield detectable losses in irrigation leachates. Therefore, the assumptions taken into consideration were that the $\mathrm{Cd}$ ions would adhere to soil or charcoal particles, or they would be absorbed by the seedlings through the roots.

Following two months of $\mathrm{Cd}$ dosing onto the soil, an analysis of the average plant material per treatment was carried out regarding different plant sections, namely the roots, stem, and leaves, as well as to the residual concentration of $\mathrm{Cd}$ ions in the soil. The summary of the results is presented in Table 1.

Table 1. $\mathrm{pH}$ and average distribution of total $\mathrm{Cd}$ in different sections of the seedlings and on the soil at the end of the data collection. ND indicates that $\mathrm{Cd}$ ions were not detected at a detection level of $0.5 \mathrm{mg} \mathrm{Cd} \mathrm{kg}^{-1}$.

\begin{tabular}{cccccc}
\hline Treatment & $\begin{array}{c}\text { Leaves } \\
(\mathbf{m g ~ C d ~ k g}\end{array}$ & $\begin{array}{c}\text { Stem } \\
\left(\mathbf{m g ~ C d ~ k g}^{-\mathbf{1}}\right)\end{array}$ & $\begin{array}{c}\text { Roots } \\
\left.\mathbf{( m g ~ C d ~ k g}^{-1}\right)\end{array}$ & $\begin{array}{c}\text { Soil } \\
\left.\mathbf{m g ~ C d ~ k g}^{-\mathbf{1}}\right)\end{array}$ & $\mathbf{p H}$ \\
\hline Control & $28.8 \pm 4.0$ & $47.4 \pm 10.3$ & $130.5 \pm 18.6$ & $24.6 \pm 4.1$ & $6.28 \pm 0.5$ \\
Lime & $\mathrm{ND}$ & $\mathrm{ND}$ & $13.0 \pm 10.9$ & $28.7 \pm 2.9$ & $7.46 \pm 0.4$ \\
Charcoal & $20.4 \pm 3.7$ & $46.6 \pm 6.3$ & $108.0 \pm 14.5$ & $18.1 \pm 0.6$ & $6.04 \pm 0.7$ \\
Charcoal + Lime & $\mathrm{ND}$ & $\mathrm{ND}$ & $\mathrm{ND}$ & $35.9 \pm 1.7$ & $7.48 \pm 0.6$ \\
\hline
\end{tabular}

ND: not detected.

The results from Table 1 indicate that both treatments with the application of lime lead to lower mobility of $\mathrm{Cd}$ ions toward different parts of the seedlings. In particular, the application of lime combined with the charcoal powder demonstrated to be the single condition without detectable concentrations of $\mathrm{Cd}$ on the plant material. These encouraging results are in accordance with others in the literature, including the recent report by Hamid et al. [7], who demonstrated that the sole application of lime on Cd-contaminated fields led to a $25 \%$ reduction of $\mathrm{Cd}$ content in rice plantations. The results herein also demonstrate 
that the sole application of lime led to detectable concentrations of $\mathrm{Cd}$ onto the seedlings, which can potentially be associated with a sum of physical and chemical factors, including the lower concentration of $\mathrm{Cd}$-adsorbing materials in the soil. Nonetheless, since our data collection did not consider sample taking during the 60 days of the experiment but rather just the initial and final concentration of $\mathrm{Cd}$, a more definite conclusion cannot be set regarding the kinetic process of $\mathrm{Cd}$ mobility in the soil. The effect of the $\mathrm{pH}$ in the soil, thus, is evidenced to be strongly correlated to the Cd mobility into the seedlings throughout the treatment, as reviewed by Hamid et al. [7].

Table 1 also demonstrates that the results obtained from the application of the charcoal powder were not as effective in controlling $\mathrm{Cd}$ mobility when compared to the treatments containing lime. These results can potentially be understood given the competitive nature of adsorption of the cations in soil with the charcoal material. It has been demonstrated by studies, such as the one by Haider et al. [17], that $\mathrm{Ca}, \mathrm{Mg}, \mathrm{Zn}, \mathrm{Mn}$, and $\mathrm{Al}$ ions compete with charcoal and carbonaceous structures in the presence of $\mathrm{Cd}$. Given the fact that a competitive analysis was not evaluated in the controlled adsorption assays described in Section 3.1, it cannot be firmly assumed that such ions would have preferential adsorption potentials when compared to $\mathrm{Cd}$ onto the charcoal particles. Nonetheless, the results describe a slightly lower concentration of $\mathrm{Cd}$ in the roots when compared to the control, which can potentially be linked to lower $\mathrm{Cd}$ mobility onto the plant materials.

The application of lime has been demonstrated in several studies to be an effective approach to control Cd mobility in pea and wheat [18], rice [19], hyacinth [20], and others. Liming has been described to not only control $\mathrm{Cd}$ mobility through $\mathrm{pH}$ shifts, but also by increasing the concentration of $\mathrm{Ca}$ ions in the soil, therefore enhancing the competition between ions and reducing $\mathrm{Cd}$ uptake by plants. The application of carbonaceous materials in Cd-contaminated soils has also been demonstrated to increase growth rates in a variety of crops, as thoroughly reviewed by Hamid et al. [7]. In this sense, the results described herein align with some other reports. Furthermore, our data describe that a combination of amendments with different mechanisms, including adsorption and $\mathrm{pH}$ control, may lead to lower mobility of $\mathrm{Cd}$ onto T. cacao seedlings.

Author Contributions: Conceptualization, C.C.C.J. and L.V.P.F.; methodology, C.E.R.R.; formal analysis, C.C.C.J., L.V.P.F. and C.E.R.R.; investigation, C.C.C.J. and L.V.P.F.; writing-original draft preparation, C.E.R.R.; writing-review and editing, C.E.R.R.; visualization, C.C.C.J. and L.V.P.F.; supervision, C.E.R.R.; project administration, C.E.R.R. All authors have read and agreed to the published version of the manuscript.

Funding: This research received no external funding.

Institutional Review Board Statement: Not applicable.

Informed Consent Statement: Not applicable.

Acknowledgments: The authors are thankful for all the support from the Soils and Waters Laboratory at EARTH University.

Conflicts of Interest: The authors declare no conflict of interest.

\section{References}

1. Wickramasuriya, A.M.; Dunwell, J.M. Cacao biotechnology: Current status and future prospects. Plant Biotech. J. 2018, 16, 4-17. [CrossRef] [PubMed]

2. Armengot, L.; Beltrán, M.J.; Schneider, M.; Simón, X.; Pérez-Neira, D. Food-energy-water nexus of different cacao production systems from a LCA approach. J. Clean Prod. 2021, 304, 126941. [CrossRef]

3. Argüello, D.; Chavez, E.; Lauryssen, F.; Vanderschueren, R.; Smolders, E.; Montalvo, D. Soil properties and agronomic factors affecting cadmium concentrations in cacao beans: A nationwide survey in Ecuador. Sci. Total Environ. 2019, 649, 120-127. [CrossRef] [PubMed]

4. Genchi, G.; Sinicropi, M.S.; Lauria, G.; Carocci, A.; Catalano, A. The Effects of Cadmium Toxicity. Int. J. Environ. Res. Public Health 2020, 17, 3782. [CrossRef] [PubMed]

5. Maddela, N.R.; Kakarla, D.; García, L.C.; Chakraborty, S.; Venkateswarlu, K.; Megharaj, M. Cocoa-laden cadmium threatens human health and cacao economy: A critical view. Sci. Total Environ. 2020, 720, 137645. [CrossRef] [PubMed] 
6. Scaccabarozzi, D.; Castillo, L.; Aromatisi, A.; Milne, L.; Búllon Castillo, A.; Muñoz-Rojas, M. Soil, Site, and Management Factors Affecting Cadmium Concentrations in Cacao-Growing Soils. Agronomy 2020, 10, 806. [CrossRef]

7. Hamid, Y.; Tang, L.; Sohail, M.I.; Cao, X.; Hussain, B.; Aziz, M.Z.; Usman, M.; He, Z.-1.; Yang, X. An explanation of soil amendments to reduce cadmium phytoavailability and transfer to food chain. Sci. Total Environ. 2019, 660, 80-96. [CrossRef] [PubMed]

8. Yang, Y.; Chen, J.; Huang, Q.; Tang, S.; Wang, J.; Hu, P.; Shao, G. Can liming reduce cadmium (Cd) accumulation in rice (Oryza sativa) in slightly acidic soils? A contradictory dynamic equilibrium between $\mathrm{Cd}$ uptake capacity of roots and Cd immobilisation in soils. Chemosphere 2018, 193, 547-556. [CrossRef] [PubMed]

9. He, Y.-B.; Huang, D.-Y.; Zhu, Q.-H.; Wang, S.; Liu, S.-L.; He, H.-B.; Zhu, H.-H.; Xu, C. A three-season field study on the in-situ remediation of $\mathrm{Cd}$-contaminated paddy soil using lime, two industrial by-products, and a low-Cd-accumulation rice cultivar. Ecotoxicol. Environ. Saf. 2017, 136, 135-141. [CrossRef] [PubMed]

10. Bian, R.; Chen, D.; Liu, X.; Cui, L.; Li, L.; Pan, G.; Xie, D.; Zheng, J.; Zhang, X.; Zheng, J.; et al. Biochar soil amendment as a solution to prevent Cd-tainted rice from China: Results from a cross-site field experiment. Ecol. Eng. 2013, 58, 378-383. [CrossRef]

11. Carter, M.R.; Gregorich, E.G. Soil Sampling and Methods of Analysis; CRC Press: Boca Raton, FL, USA, 2007.

12. Wang, S.-Y.; Tsai, M.-H.; Lo, S.-F.; Tsai, M.-J. Effects of manufacturing conditions on the adsorption capacity of heavy metal ions by Makino bamboo charcoal. Bioresour. Technol. 2008, 99, 7027-7033. [CrossRef] [PubMed]

13. Thommes, M.; Kaneko, K.; Neimark, A.V.; Olivier, J.P.; Rodriguez-Reinoso, F.; Rouquerol, J.; Sing, K.S.W. Physisorption of gases, with special reference to the evaluation of surface area and pore size distribution (IUPAC Technical Report). J. Pure Appl. Chem. 2015, 87, 1051-1069. [CrossRef]

14. Kurniawan, A.; Ismadji, S. Potential utilization of Jatropha curcas L. press-cake residue as new precursor for activated carbon preparation: Application in methylene blue removal from aqueous solution. J. Taiwan Inst. Chem. Eng. 2011, 42, 826-836. [CrossRef]

15. Azizian, S. Kinetic models of sorption: A theoretical analysis. J. Colloid Interface Sci. 2004, 276, 47-52. [CrossRef] [PubMed]

16. Oyetade, O.A.; Nyamori, V.O.; Jonnalagadda, S.B.; Martincigh, B.S.J.D.W.T. Removal of $\mathrm{Cd}^{2+}$ and $\mathrm{Hg}^{2+}$ from aqueous solutions by adsorption onto nitrogen-functionalized carbon nanotubes. Desalin. Water Treat. 2018, 108, 253-267. [CrossRef]

17. Haider, F.U.; Liqun, C.; Coulter, J.A.; Cheema, S.A.; Wu, J.; Zhang, R.; Wenjun, M.; Farooq, M. Cadmium toxicity in plants: Impacts and remediation strategies. Ecotoxicol. Environ. Saf. 2021, 211, 111887. [CrossRef] [PubMed]

18. Castaldi, P.; Melis, P.; Silvetti, M.; Deiana, P.; Garau, G. Influence of pea and wheat growth on Pb, Cd, and Zn mobility and soil biological status in a polluted amended soil. Geoderma 2009, 151, 241-248. [CrossRef]

19. Xiao, R.; Huang, Z.; Li, X.; Chen, W.; Deng, Y.; Han, C. Lime and Phosphate Amendment Can Significantly Reduce Uptake of Cd and $\mathrm{Pb}$ by Field-Grown Rice. Sustainability 2017, 9, 430. [CrossRef]

20. Singh, J.; Kalamdhad, A.S. Effects of lime on bioavailability and leachability of heavy metals during agitated pile composting of water hyacinth. Bioresour. Technol. 2013, 138, 148-155. [CrossRef] [PubMed] 